\title{
Endothelial dysfunction, cellular adhesion molecules and the metabolic syndrome
}

Citation for published version (APA):

Schram, M. T., \& Stehouwer, C. D. (2005). Endothelial dysfunction, cellular adhesion molecules and the metabolic syndrome. Hormone and Metabolic Research, 37 Suppl 1, 49-55. https://doi.org/10.1055/s2005-861363

Document status and date:

Published: 01/01/2005

DOI:

10.1055/s-2005-861363

Document Version:

Publisher's PDF, also known as Version of record

Document license:

Taverne

Please check the document version of this publication:

- A submitted manuscript is the version of the article upon submission and before peer-review. There can be important differences between the submitted version and the official published version of record.

People interested in the research are advised to contact the author for the final version of the publication, or visit the DOI to the publisher's website.

- The final author version and the galley proof are versions of the publication after peer review.

- The final published version features the final layout of the paper including the volume, issue and page numbers.

Link to publication

\footnotetext{
General rights rights.

- You may freely distribute the URL identifying the publication in the public portal. please follow below link for the End User Agreement:

www.umlib.nl/taverne-license

Take down policy

If you believe that this document breaches copyright please contact us at:

repository@maastrichtuniversity.nl

providing details and we will investigate your claim.
}

Copyright and moral rights for the publications made accessible in the public portal are retained by the authors and/or other copyright owners and it is a condition of accessing publications that users recognise and abide by the legal requirements associated with these

- Users may download and print one copy of any publication from the public portal for the purpose of private study or research.

- You may not further distribute the material or use it for any profit-making activity or commercial gain

If the publication is distributed under the terms of Article $25 \mathrm{fa}$ of the Dutch Copyright Act, indicated by the "Taverne" license above, 


\section{T. Schram ${ }^{1}$ \\ C. D. A. Stehouwer ${ }^{2}$ \\ Endothelial Dysfunction, Cellular Adhesion Molecules and the Metabolic Syndrome}

\begin{abstract}
Over the last two decades, it has become evident that the endothelium is more than an inert, single-cell lining covering the internal surface of blood vessels. Normally, the endothelium actively decreases vascular tone, maintains vascular permeability within narrow bounds, inhibits platelet adhesion and aggregation, limits activation of the coagulation system, and stimulates fibrinolysis. Endothelium dysfunction can be considered present when its functions, either in the basal state or after stimulation, are altered in a way that is inappropriate to the preservation of organ function. Endothelial dysfunction has been associated to many cardiovascular risk factors including diabetes, hyperten-
\end{abstract}

sion and hypercholesterolemia. In addition, endothelial dysfunction may play a crucial role in the development and progression of atherosclerosis. This review will give a brief overview of the different methods to assess endothelial function, and then will focus on the current knowledge on soluble cellular adhesion molecules in relation to the metabolic syndrome and type 2 diabetes.

\section{Key words}

Type 2 diabetes - Cellular adhesion molecules · Endothelium · Metabolic syndrome - Cardiovascular disease

\section{How to Measure Endothelial Function}

Several methods to measure endothelial function in vivo are currently known. It should be noted that there is no direct measurement of endothelial function available in humans. The techniques described below provide reasonable but imperfect estimates of endothelial function in humans. Since 1986, direct measurement of coronary artery relaxation after acetylcholine infusions has been used to assess endothelial function in patients with coronary artery disease [1]. However, the invasive nature of this technique means that it is not a suitable method for measuring endothelial function in other patient groups.
Another technique for measuring endothelial function is straingauge plethysmography. The response of the forearm vascular bed to infusion of vasodilator or vasoconstrictive agents is determined by direct infusion of these agents into the brachial artery. However, this method is time-consuming and invasive, and therefore not suitable for usage in large populations.

In 1992, a new non-invasive flow-mediated vasodilation technique was introduced by Celermajer et al. [2] This technique has now been used by numerous groups worldwide. The International Brachial Artery Reactivity Task Force has extensively described the technique's methods, along with the technical and interpretive limitations to this technique [3].

\section{Affiliation \\ ${ }^{1}$ Department of Internal Medicine, Erasmus Medical Center, Rotterdam ${ }^{2}$ Department of Internal Medicine, University Hospital Maastricht, The Netherlands}

Correspondence

Prof. C. D. A. Stehouwer · Department of Internal Medicine, University Hospital Maastricht · PO Box 5800 . 6202 AZ Maastricht · The Netherlands · Phone: +31 (0)43 3877041 ·E-Mail: csteh@sint.azm.nl

Received 14 October $2004 \cdot$ Accepted after revision 10 February 2005 
Endothelial function can also be measured using plasma levels of markers of endothelial function such as von Willebrand factor and soluble cellular adhesion molecules. Like other techniques, this concept is based on several assumptions - first, that cell types other than endothelial cells are not an important source of these markers. Second, that synthesis is more important than clearance. Third, that endothelial function in the microcirculatory parallels that in large arteries since microvascular endothelium has a very large surface area and synthetic capacity, and may therefore be the most important source of these endothelial markers. Information on the validity of these assumptions is scarce. However, plasma levels of soluble cell adhesion molecules are easy to determine in large populations. These measurements are relatively independent of observer variability and less time-consuming than other techniques.

\section{Endothelial Cell Adhesion Molecules}

Cellular adhesion molecules mediate the attachment and transmigration of leukocytes across the endothelial surface in response to several inflammatory cytokines (Fig.1), and are hypothesized to play an important role in the initiation of atherosclerosis [4]. Three groups of cellular adhesion molecules have been described: integrins, selectins, and members of the immunoglobulin family. The focus of this review will be on the latter two.

Several selectins have been found on the endothelium - L-selectin, P-selectin, and E-selectin. The latter is exclusively found on the surface of stimulated endothelial cells. This specificity provides an opportunity for studying the pathophysiological aspects of endothelial function. E-selectin binds neutrophils, monocytes, eosinophils, basophils, natural killer (NK) cells, and subsets of lymphocytes. This adhesion molecule has been shown to be important in the initial steps of leukocyte extravasation into inflamed tissues [5]. Levels of soluble E-selectin (sE-selectin) in plasma correlate to its membrane-bound expression [6].

Vascular cell adhesion molecule-1 (VCAM-1) is a membranebound adhesion molecule receptor and a member of the immunoglobulin family. VCAM-1 is thought to be a ligand for leukocyte integrins that allow tethering and rolling of monocytes and lymphocytes as well as firm attachment and transendothelial migration of leukocytes. The membrane-bound protein is normally expressed at low levels by endothelial cells, smooth muscle cells, tissue macrophages, lymphoid dendritic cells and renal tubular cells. Soluble forms of VCAM-1 (sVCAM-1) are detectable in plasma, and are reported to parallel the expression of the membrane-bound form on endothelial cells [7]. Several stimuli, including cytokines, modified lipoproteins, advanced glycation end-products, increased blood pressure, and oxidants, can upregulate VCAM-1 expression.

Intercellular adhesion molecule-1 (ICAM-1), also a member of the immunoglobulin family, is a membrane-bound adhesion molecule receptor for monocytes, lymphocytes and neutrophils, and functions as a receptor for soluble fibrinogen. ICAM-1 is expressed by endothelial cells, smooth-muscle cells and monocytes. Like sE-selectin and sVCAM-1 levels, soluble ICAM-1 (sI-

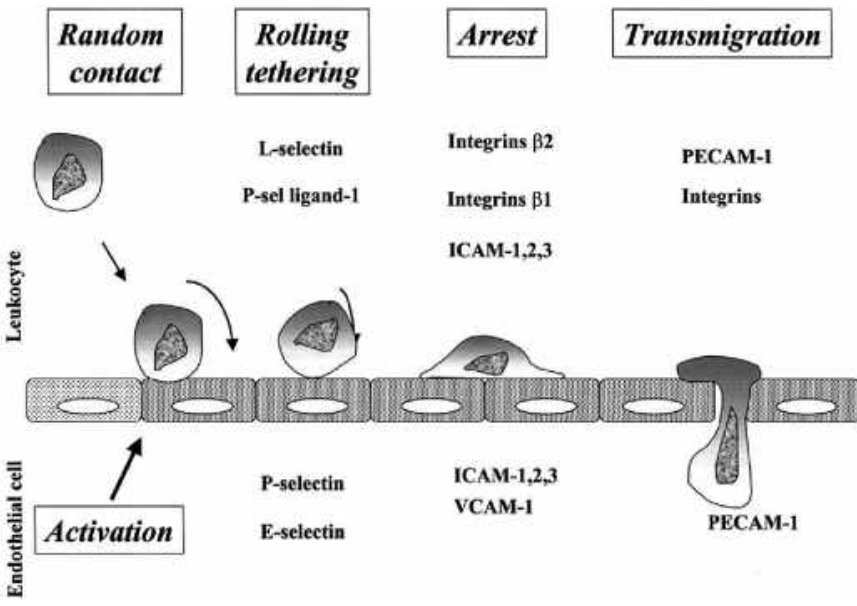

Fig. 1 Leukocyte-endothelial cell interactions during the initial steps of leukocyte migration, and the role of the various adhesion molecules in this process (Reprinted with permission from Blankenberg $S$ et al. Atherosclerosis 170: $191-203,2003)$.

CAM-1) levels are detectable in plasma, and these levels are directly associated with membrane-bound protein expression [6]. ICAM-1 levels can be upregulated by inflammatory cytokines, but can also increase after exposure to high glucose levels. Accumulating data imply that selectins mediate initial rolling of leukocytes along the endothelium, and that VCAM-1 and ICAM-1 play important roles in the firm attachment and transendothelial migration of leukocytes.

\section{Associations Between Cellular Adhesion Molecules and Characteristics of the Metabolic Syndrome}

Type 2 diabetes is often accompanied by cardiovascular risk factors such as hypertension, obesity, dyslipidemia, and insulin resistance. The combined presence of these risk factors is referred to as the metabolic syndrome. Many variables included in the metabolic syndrome are associated with endothelial dysfunction. The following section will discuss the associations between endothelial cell adhesion molecules and characteristics of the metabolic syndrome.

\section{Hypertension}

High blood pressure increases shear stress on the endothelium, and may result in endothelial cell activation or even damage. Several studies have reported increased levels of sVCAM-1, sICAM-1 and sE-selectin in the presence of hypertension, although conflicting results exist. Some studies only investigated sE-selectin in hypertensive individuals, and found increased levels compared to normotensive individuals $[8,9]$, while others demonstrated elevated SVCAM-1 and/or sICAM-1 levels but no increase in sE-selectin levels in hypertensive individuals [1012]. Two studies found elevations in all three soluble cellular adhesion molecules in hypertensive individuals [13,14]. In addition, a transient elevation of SVCAM-1, sICAM-1 and sE-selectin after a cold-pressor test has been reported in both normotensive and hypertensive individuals [14]. Others investigated the effects of obesity and hypertension, reporting that hypertensive and normotensive obese men showed elevated levels of sVCAM-1, sICAM-1 and sE-selectin [15]. However, these levels were 
unrelated to the presence of hypertension, suggesting that the changes in endothelial function were secondary to obesity rather than high blood pressure.

The main problem in the above studies was the relatively small number of individuals included; none of these studies included more than 45 hypertensive individuals. This may, to some extent, explain the conflicting results that have been reported, and some of these may be due to chance. In that respect, larger studies may provide more consistent information. The ARIC study showed significantly elevated levels of sE-selectin in hypertension, while levels of sVCAM- 1 and sICAM-1 were similar in hypertensive and normotensive individuals [16]. However, these results were based on a selection of the original population of about 792 individuals based on the presence or absence of coronary heart disease, and therefore do not represent these relationships in the general population. The Physicians' Health Study investigated the association of sICAM-1 levels with measures of blood pressure in a large sample of middle-aged men ( $n=948)$, and showed a strong positive association of sICAM- 1 levels with both systolic and diastolic blood pressure [17].

Some reports dealt with specific issues that are important in hypertension. Kuroda et al. [18] showed that sVCAM-1 is a marker of left ventricular hypertrophy in hypertensive individuals, while levels of sICAM-1 and sE-selectin were not. In addition, levels of sE-selectin were shown to be elevated in salt-sensitive compared to salt-resistant hypertensive individuals, while sVCAM-1 and sICAM-1 levels were similar between the groups [19]. These two studies included somewhat more individuals in their analyses; however, the numbers still did not exceed a hundred, and the results were not confirmed by others.

Taken together, we can conclude that results among reports remain conflicting. However, all studies described above showed an increase in at least one of the three cellular adhesion molecules. This seems to imply that increased hemodynamic stress on the endothelium caused by hypertension might raise the expression of endothelial cell adhesion molecules. However, the reverse may also be true - increased expression of endothelial cell adhesion molecules may contribute to the development of hypertension due to failure of the endothelium to perform its tasks correctly in regulating vascular tone.

\section{Obesity}

Several studies have investigated the association of obesity with soluble cellular adhesion molecules. Adipose tissue is thought to be able to produce inflammatory markers such as interleukin-6 and tumor necrosis factor $\alpha$ (TNF- $\alpha$ ), which in turn are able to stimulate the expression of cellular adhesion molecules. Higher levels of sE-selectin in obesity have been described in both men [16] and women [20], including positive correlations with body mass index or body fat [21-23]. Conflicting results exist for the relation of sVCAM-1 and sICAM-1 levels with obesity. Some reports have shown an association between both SVCAM-1 and sICAM-1 on the one hand, and body mass index on the other $[15,17,24,25]$, while others have not $[16,26]$. However, the latter included a subgroup of the ARIC study with cardiovascular disease [16] and a population of women with polycystic ovary syndrome [26], and may not pertain to the general population. The degree of obesity in the individuals included may of course have an effect on the results of the study. One study investigated sICAM-1 levels in morbid obesity (body mass index above $35 \mathrm{~kg} / \mathrm{m}^{2}$ ), and showed elevated sICAM-1 levels compared to non-obese individuals [27].

When obesity is accompanied by type 2 diabetes, levels of sE-selectin and, in most cases, sICAM-1 are associated with measures of obesity $[22,23,28,29]$. Soluble VCAM-1 appears to be associated with obesity in type 2 diabetic Pima Indians [23], while no such association has been found in Caucasian and Japanese individuals $[22,28,29]$. Another study on non-diabetic Pima Indians demonstrated an association between SICAM-1 and percentage of total body fat, but not sE-selectin levels [21].

Studies on the effects of weight loss on these molecules strongly suggest that obesity is causally involved in elevated levels of endothelial cell adhesion molecules. Levels of all three endothelial cell adhesion molecules have been reported to decrease after weight loss [15,20,27].

Taken together, the evidence suggests that there is indeed an association between obesity and the expression of cellular adhesion molecules. This suggests that obesity is involved in the development of endothelial dysfunction. Studies on the effects of weight loss suggest endothelial dysfunction caused by obesity is reversible. Mechanisms that may explain these relationships include increased stress to the cardiovascular system in overweight patients, increased production of inflammatory markers by adipocytes, or metabolic stimulus such as the effect of insulin on the endothelium.

\section{Dyslipidemia}

Hypercholesterolemia (although not a consistent feature of the metabolic syndrome) [30 - 32] has been associated with elevated levels of sVCAM-1, sICAM-1 and sE-selectin. However, in accordance with the previous features of the metabolic syndrome, conflicting results have been published with regard to endothelial cell adhesion molecules and dyslipidemia. No differences in sVCAM-1 levels have been reported for hypercholesterolemia [33-36], while levels both elevated $[33,37,38]$ and comparable to controls have been reported for sICAM-1 and sE-selectin [34-36,39]. Two reports on hypertriglyceridemia have demonstrated elevated levels of all three endothelial cell adhesion molecules $[33,40]$. Only one study reported increased sICAM-1 levels in familial hypercholesterolemia (FH) [41], while others showed no differences in sVCAM-1, sICAM-1 or sE-selectin levels between FH and non-FH and control subjects [36,42]. Calabresi et al. [43] specifically investigated the association between low HDL cholesterol and endothelial cell adhesion molecules, and found significant inverse associations of HDL cholesterol and sICAM-1 with sE-selectin, but not with sVCAM-1. However, since only one study has reported this finding, this observation needs to be confirmed.

Taken together, these findings suggest that dyslipidemia does have an effect on cellular adhesion molecule levels. Hypercholesterolemia may have a more specific effect on sICAM-1 and sE-selectin levels, whereas triglycerides and HDL cholesterol levels would also affect sVCAM-1 levels. It seems likely that changes 
in lipid profile do have some effect on the expression of endothelial cell adhesion molecules.

\section{Insulin Resistance}

Several studies have investigated the association of endothelial cell adhesion molecules with insulin resistance in non-diabetic individuals. These studies showed that levels of sVCAM-1, sICAM-1 and sE-selectin were significantly elevated in insulin-resistant individuals [21,44-47], although not all studies demonstrated this for sVCAM-1 $[21,46]$. One study investigated this issue in Japanese individuals, and demonstrated increased sE-selectin levels in the insulin-resistant state, while no difference in sVCAM-1 or sICAM-1 levels was found [47].

In Caucasians, some population-based sample studies have investigated the association between insulin resistance and cellular adhesion molecules. Hak et al [46]. investigated a large group of non-diabetic individuals from the Rotterdam study, and found an association of sICAM-1 with post-load insulin levels, but not with sVCAM-1. In contrast, the Hoorn study did show an association of sVCAM-1 with glucose tolerance status in a population that also included diabetic individuals [48]. Somewhat smaller studies including non-diabetic, impaired glucose tolerance and type 2 diabetic individuals in general demonstrated increased levels of sVCAM-1, sICAM-1 and sE-selectin in the insulin-resistant state [49-51], although one study observed no association at all [52]. Studies that included type 2 diabetic individuals only consistently showed increased levels of sVCAM-1 and sE-selectin in insulin-resistant individuals; however, the results on sICAM-1 remain inconclusive $[28,53]$.

In conclusion, there is a trend among studies that shows increased levels of all three endothelial cell adhesion molecules in insulin resistant states whether or not glucose tolerance is normal or type 2 diabetes is present.

\section{Type 2 diabetes}

Numerous studies have investigated the association between endothelial cell adhesion molecules and type 2 diabetes. As in the previous sections, conflicting results have been reported. One of the earliest reports showed increased levels of sVCAM- 1 and sEselectin with no difference in sICAM-1 levels in type 2 diabetic individuals compared to controls [54]. Many other findings have been reported; an increase in SICAM-1 with no change in sVCAM-1 and sE-selectin [55], and increase in sVCAM-1 and sICAM-1 with no change in sE-selectin [56], no change in any of the cellular adhesion molecules [52,57], or an increase in all three cellular adhesion molecules $[50,58,59]$. However, the majority of the studies show increased levels of endothelial cell adhesion molecules in type 2 diabetic compared to non-diabetic individuals. In addition, the larger studies, including over 100 type 2 diabetic patients, consistently show that levels of sVCAM-1, sICAM-1 and sE-selectin are elevated compared to non-diabetic controls [59-61].

Other studies have investigated whether the presence of diabetic complications was associated with cellular adhesion molecules. With regard to nephropathy, Schmidt et al. [62] were among the first to report increased sVCAM-1 levels in diabetic patients with microalbuminuria. Others followed by demonstrating increased
sVCAM-1 and/or sICAM-1 levels in the presence of nephropathy [57,63], while Lim et al. [64] could not demonstrate any increase in sVCAM-1 and sICAM-1 levels in diabetic individuals with microalbuminuria compared to those with normoalbuminuria. In addition to these cross-sectional studies, the Hoorn study demonstrated that the development of elevated urinary albumin excretion rate during a follow-up of 6.1 years was significantly associated with levels of sVCAM-1. [65] Apart from that, Stehouwer and colleagues reported sVCAM- 1 and sE-selectin to be interrelated to increased urinary albumin excretion in type 2 diabetes during a nine-year follow-up. [66] These two longitudinal studies provide strong evidence that endothelial dysfunction is involved in the early development of nephropathy.

Results are more in agreement with regard to retinopathy; Japanese type 2 diabetic individuals with proliferative retinopathy showed a significant increase in SVCAM-1 compared to those without proliferative retinopathy [67]. This observation was confirmed in diabetic patients with retinopathy but without macrovascular disease [53]. The latter study also investigated sE-selectin levels and found similar results, increased levels in the presence of retinopathy.

Levels of sVCAM-1 and sE-selectin were either increased [53] or remained similar in type 2 diabetes [64]. The Hoorn study provided longitudinal data on this subject, as increased sVCAM1 levels were significantly associated with increased risk of cardiovascular mortality (relative risk and [95\% confidence interval] were 1.10 [1.05-1.15] per $100 \mu \mathrm{g} / \mathrm{l}$ increase in sVACM-1) [48].

Taken together, these results suggest that levels of cellular adhesion molecules are increased in type 2 diabetes compared to levels in non-diabetic individuals. With regard to micro- and macrovascular complications, the indications are that cellular adhesion molecules increase in the presence of retinopathy, nephropathy and cardiovascular disease. Longitudinal studies suggest a pathophysiological role of endothelial function in the development of nephropathy and cardiovascular disease.

\section{Prognostic Information from Cellular Adhesion Molecules}

\section{Type 2 diabetes}

Only little information is available on the prognostic value of cellular adhesion molecules in the development of type 2 diabetes. Very recently, this issue was investigated in the Nurses' Health Study [68], which included 737 incident cases of type 2 diabetes and 785 age- and race-matched controls followed up for 10 years. These investigators found that elevated sE-selectin and sICAM-1 levels predicted incident type 2 diabetes in these women, independently of known risk factors. Relative risks of diabetes were $7.5(5.1-11.1)$ for sE-selectin and $4.3(3.0-6.2)$ for sICAM-1 in the highest quintile relative to the lowest quintile of cellular adhesion molecule levels. The association between SVCAM-1 and incident diabetes was not independent of known diabetes risk factors. These results suggest a causal relationship between microvascular dysfunction and insulin resistance as previously implied [69]. This hypothesis is supported by the findings of the ARIC study, which has demonstrated that retinal microangiopathy predicts the development of type 2 diabetes [70]. 


\section{Cardiovascular disease in type 2 diabetes}

Somewhat more information is available on the prognostic value of cellular adhesion molecules in relation to cardiovascular disease in type 2 diabetic individuals. For instance, the Hoorn Study reported that type 2 diabetic individuals with high SVCAM-1 and sICAM-1 levels are at increased risk of cardiovascular death $[48,61]$. The relative risks for cardiovascular mortality in type 2 diabetic individuals were similar to those in non-diabetic individuals. However, a much larger population would probably be necessary to provide evidence of any interaction between diabetes and adhesion molecule levels in this relationship. In addition, a 10-year follow-up study on type 2 diabetic individuals reported associations between SVCAM-1 and sE-selectin and allcause mortality [66].

In summary, only few studies have investigated the prognostic value of cellular adhesion molecules in individuals with characteristics of the metabolic syndrome or diabetes. Importantly, the one study that did investigate the role of cellular adhesion molecules in the development of type 2 diabetes showed a markedly high relative risk, suggesting that endothelial dysfunction is indeed an important pathophysiological pathway leading to type 2 diabetes. However, these results would need to be extended and confirmed by others before drawing any final conclusions.

\section{Conclusions}

Cellular adhesion molecules may play an important role in the development of the metabolic syndrome and type 2 diabetes, as well as in their cardiovascular complications. All three cellular adhesion molecules, sVCAM-1, sICAM-1 and sE-selectin, are frequently investigated to improve our knowledge on endothelial function. The endothelium is thought to be the major source of the soluble forms of these molecules. Strong evidence exists that increased levels reflect an alteration of endothelial function, which may have pathophysiological consequences on the characteristics of the metabolic syndrome and type 2 diabetes. The strongest evidence is provided by longitudinal studies that show an association between cellular adhesion molecules and development of type 2 diabetes and its cardiovascular complications. Taken together, these results support the concept that endothelial dysfunction is an important pathway leading to type 2 diabetes and cardiovascular disease.

\section{References}

${ }^{1}$ Ludmer PL, Selwyn AP, Shook TL, Wayne RR, Mudge GH, Alexander RW, Ganz P. Paradoxical vasoconstriction induced by acetylcholine in atherosclerotic coronary arteries. N Engl J Med 1986; 315: 1046 - 1051

${ }^{2}$ Celermajer DS, Sorensen KE, Gooch VM, Spiegelhalter DJ, Miller OI, Sullivan ID, Lloyd JK, Deanfield JE. Non-invasive detection of endothelial dysfunction in children and adults at risk of atherosclerosis. Lancet. 1992; 340: $1111-1115$

${ }^{3}$ Corretti MC, Anderson TJ, Benjamin EJ, Celermajer D, Charbonneau F, Creager MA, Deanfield J, Drexler H, Gerhard-Herman M, Herrington $D$, Vallance P, Vita J, Vogel R. Guidelines for the ultrasound assessment of endothelial-dependent flow-mediated vasodilation of the brachial artery: a report of the International Brachial Artery Reactivity Task Force. J Am Coll Cardiol. 2002; 39: 257-265

${ }^{4}$ Ross R. Atherosclerosis - an inflammatory disease. N Engl J Med. 1999; 340: $115-126$
${ }^{5}$ Wagers AJ, Lowe JB, Kansas GS. An important role for the alpha 1,3 fucosyltransferase, FucT-VII, in leukocyte adhesion to E-selectin. Blood. 1996; 88: 2125-2132

${ }^{6}$ Leeuwenberg JF, Smeets EF, Neefjes JJ, Shaffer MA, Cinek T, Jeunhomme TM, Ahern TJ, Buurman WA. E-selectin and intercellular adhesion molecule- 1 are released by activated human endothelial cells in vitro. Immunology. 1992; 77: 543-549

${ }^{7}$ Schmidt AM, Hori O, Chen JX, Li JF, Crandall J, Zhang J, Cao R, Yan SD, Brett J, Stern D. Advanced glycation endproducts interacting with their endothelial receptor induce expression of vascular cell adhesion molecule-1 (VCAM-1) in cultured human endothelial cells and in mice. A potential mechanism for the accelerated vasculopathy of diabetes. J Clin Invest. 1995; 96: 1395 - 1403

${ }^{8}$ Blann AD, Tse W, Maxwell SJ, Waite MA. Increased levels of the soluble adhesion molecule E-selectin in essential hypertension. J Hypertens. 1994; $12: 925-928$

${ }^{9}$ De Caterina R, Ghiadoni L, Taddei S, Virdis A, Almerigogna F, Basta G, Lazzerini G, Bernini W, Salvetti A. Soluble E-selectin in essential hypertension: a correlate of vascular structural changes. Am J Hypertens. 2001; 14: 259-266

${ }^{10}$ Hlubocka Z, Umnerova V, Heller S, Peleska J, Jindra A, Jachymova M, Kvasnicka J, Horky K, Aschermann M. Circulating intercellular cell adhesion molecule-1, endothelin-1 and von Willebrand factor-markers of endothelial dysfunction in uncomplicated essential hypertension: the effect of treatment with ACE inhibitors. J Hum Hypertens 2002; 16: $557-562$

${ }^{11}$ DeSouza CA, Dengel DR, Macko RF, Cox K, Seals DR. Elevated levels of circulating cell adhesion molecules in uncomplicated essential hypertension. Am J Hypertens 1997; 10: 1335-1341

12 Preston RA, Ledford M, Materson BJ, Baltodano NM, Memon A, Alonso A. Effects of severe, uncontrolled hypertension on endothelial activation: soluble vascular cell adhesion molecule-1, soluble intercellular adhesion molecule-1 and von Willebrand factor. J Hypertens 2002; 20: $871-877$

${ }^{13}$ Cottone S, Mule G, Amato F, Riccobene R, Vadala A, Lorito MC, Raspanti F, Cerasola G. Amplified biochemical activation of endothelial function in hypertension associated with moderate to severe renal failure. J Nephrol 2002; 15: 643-648

${ }^{14}$ Buemi M, Allegra A, Aloisi C, Corica F, Alonci A, Ruello A, Montalto G, Frisina N. Cold pressor test raises serum concentrations of ICAM-1, VCAM-1, and E-selectin in normotensive and hypertensive patients. Hypertension 1997; 30: 845-847

${ }^{15}$ Ferri C, Desideri G, Valenti M, Bellini C, Pasin M, Santucci A, De Mattia G. Early upregulation of endothelial adhesion molecules in obese hypertensive men. Hypertension 1999; 34: 568-573

${ }^{16}$ Hwang SJ, Ballantyne CM, Sharrett AR, Smith LC, Davis CE, Gotto AM Jr, Boerwinkle E. Circulating adhesion molecules VCAM-1, ICAM-1, and E-selectin in carotid atherosclerosis and incident coronary heart disease cases: the Atherosclerosis Risk In Communities (ARIC) study. Circulation 1997; 96: 4219-4225

${ }^{17}$ Rohde LE, Hennekens CH, Ridker PM. Cross-sectional study of soluble intercellular adhesion molecule-1 and cardiovascular risk factors in apparently healthy men. Arterioscler Thromb Vasc Biol 1999; 19: $1595-1599$

${ }^{18}$ Kuroda YT, Komamura K, Tatsumi R, Mori K, Yoneda K, Katayama Y, Shigemoto S, Miyatake K, Hanafusa T. Vascular cell adhesion molecule- 1 as a biochemical marker of left ventricular mass in the patients with hypertension. Am J Hypertens 2001; 14: 868-872

${ }^{19}$ Ferri C, Bellini C, Desideri G, Giuliani E, De Siati L, Cicogna S, Santucci A. Clustering of endothelial markers of vascular damage in human salt-sensitive hypertension: influence of dietary sodium load and depletion. Hypertension 1998; 32: $862-868$

20 Ito H, Ohshima A, Inoue M, Ohto N, Nakasuga K, Kaji Y, Maruyama T, Nishioka K. Weight reduction decreases soluble cellular adhesion molecules in obese women. Clin Exp Pharmacol Physiol 2002; 29: $399-404$

${ }^{21}$ Weyer C, Yudkin JS, Stehouwer CD, Schalkwijk CG, Pratley RE, Tataranni PA. Humoral markers of inflammation and endothelial dysfunction in relation to adiposity and in vivo insulin action in Pima Indians. Atherosclerosis 2002; 161: 233-242

${ }^{22}$ Matsumoto K, Sera Y, Abe Y, Tominaga T, Horikami K, Hirao K, Ueki Y, Miyake S. High serum concentrations of soluble E-selectin correlate with obesity but not fat distribution in patients with type 2 diabetes mellitus. Metabolism 2002; 51: 932 - 934 
${ }^{23}$ Krakoff J, Funahashi T, Stehouwer CD, Schalkwijk CG, Tanaka S, Matsuzawa Y, Kobes S, Tataranni PA, Hanson RL, Knowler WC, Lindsay RS. Inflammatory markers, adiponectin, and risk of type 2 diabetes in the Pima Indian. Diabetes Care 2003; 26: 1745 - 1751

${ }^{24}$ Straczkowski M, Lewczuk P, Dzienis-Straczkowska S, Kowalska I, Stepien A, Kinalska I. Elevated soluble intercellular adhesion molecule-1 levels in obesity: relationship to insulin resistance and tumor necrosis factor-alpha system activity. Metabolism 2002; 51: 75 - 78

${ }^{25}$ Porreca E, di Febbo C, Fusco L, Moretta V, di Nisio M, Cuccurullo F. Soluble thrombomodulin and vascular adhesion molecule- 1 are associated to leptin plasma levels in obese women. Atherosclerosis 2004; 172: $175-180$

${ }^{26}$ Escobar-Morreale HF, Villuendas G, Botella-Carretero JI, Sancho J, San Millan JL. Obesity, and not insulin resistance, is the major determinant of serum inflammatory cardiovascular risk markers in pre-menopausal women. Diabetologia 2003; 46: 625-633

27 Pontiroli AE, Pizzocri P, Koprivec D, Vedani P, Marchi M, Arcelloni C, Paroni R, Esposito K, Giugliano D. Body weight and glucose metabolism have a different effect on circulating levels of ICAM-1, E-selectin, and endothelin-1 in humans. Eur J Endocrinol 2004; 150: 195- 200

${ }^{28}$ Leinonen E, Hurt-Camejo E, Wiklund O, Hulten LM, Hiukka A, Taskinen MR. Insulin resistance and adiposity correlate with acute-phase reaction and soluble cell adhesion molecules in type 2 diabetes. Atherosclerosis 2003; 166: 387-394

${ }^{29}$ Bagg W, Ferri C, Desideri G, Gamble G, Ockelford P, Braatvedt GD. The influences of obesity and glycemic control on endothelial activation in patients with type 2 diabetes. J Clin Endocrinol Metab 2001; 86: $5491-5497$

${ }^{30}$ Report of a WHO Consultation. In: Alwan A, King H (eds). Definition, Diagnosis and Classification of Diabetes Mellitus. Geneva: World Health Organization, Department of Noncommunicable Disease Surveillance, 1999: 1-59

${ }^{31}$ Balkau B, Charles MA, Drivsholm T, Borch-Johnsen K, Wareham N, Yudkin JS, Morris R, Zavaroni I, van Dam R, Feskins E, Gabriel R, Diet $\mathrm{M}$, Nilsson P, Hedblad B. Frequency of the WHO metabolic syndrome in European cohorts, and an alternative definition of an insulin resistance syndrome. Diabetes Metab 2002; 28: 364-376

32 Executive Summary of The Third Report of The National Cholesterol Education Program (NCEP). Expert Panel on Detection, Evaluation, And Treatment of High Blood Cholesterol In Adults (Adult Treatment Panel III). JAMA 2001; 285: 2486 - 2497

${ }^{33}$ Hackman A, Abe Y, Insull W Jr, Pownall H, Smith L, Dunn K, Gotto AM $\mathrm{Jr}$, Ballantyne CM. Levels of soluble cell adhesion molecules in patients with dyslipidemia. Circulation 1996; 93: 1334-1338

${ }^{34}$ Morisaki N, Saito I, Tamura K, Tashiro J, Masuda M, Kanzaki T, Watanabe S, Masuda Y, Saito Y. New indices of ischemic heart disease and aging: studies on the serum levels of soluble intercellular adhesion molecule-1 (ICAM-1) and soluble vascular cell adhesion molecule-1 (VCAM-1) in patients with hypercholesterolemia and ischemic heart disease. Atherosclerosis 1997; 131: 43-48

35 Blann AD, Seigneur M, Steiner M, Miller JP, McCollum CN. Circulating ICAM-1 and VCAM-1 in peripheral artery disease and hypercholesterolaemia: relationship to the location of atherosclerotic disease, smoking, and in the prediction of adverse events. Thromb Haemost 1998; 79: $1080-1085$

${ }^{36}$ Nawawi H, Osman NS, Annuar R, Khalid BA, Yusoff K. Soluble intercellular adhesion molecule- 1 and interleukin- 6 levels reflect endothelial dysfunction in patients with primary hypercholesterolaemia treated with atorvastatin. Atherosclerosis 2003; 169: 283-291

${ }^{37}$ Kvasnicka T, Kvasnicka J, Ceska R, Vrablik M. Increase of inflammatory state in overweight adults with combined hyperlipidemia. Nutr Metab Cardiovasc Dis 2003; 13: 227-231

38 Kvasnicka T, Kvasnicka J, Ceska R, Grauova B, Vrablik M. Increasing plasma levels of soluble cell adhesion molecules (sE-Selectin, sP-Selectin and sICAM-1) in overweight adults with combined hyperlipidemia. Sb Lek 2001; 102: 473-477

${ }^{39}$ Blann AD, Davis A, Miller JP, McCollum CN. Von Willebrand factor and soluble E-selectin in hyperlipidaemia: relationship to lipids and vascular disease. Am J Hematol 1997; 55: 15-23

${ }^{40}$ Abe Y, El Masri B, Kimball KT, Pownall H, Reilly CF, Osmundsen K, Smith CW, Ballantyne CM. Soluble cell adhesion molecules in hypertriglyceridemia and potential significance on monocyte adhesion. Arterioscler Thromb Vasc Biol 1998; 18: 723 - 731

${ }^{41}$ Sampietro T, Tuoni M, Ferdeghini M, Ciardi A, Marraccini P, Prontera C, Sassi G, Taddei M, Bionda A. Plasma cholesterol regulates soluble cell adhesion molecule expression in familial hypercholesterolemia. Circulation 1997; 96: 1381 - 1385

42 Paiker JE, Raal FJ, Veller M, von Arb M, Chetty N, Naran NH. Cell adhesion molecules - can they be used to predict coronary artery disease in patients with familial hypercholesterolaemia? Clin Chim Acta 2000; 293: $105-113$

${ }^{43}$ Calabresi L, Gomaraschi M, Villa B, Omoboni L, Dmitrieff C, Franceschini G. Elevated soluble cellular adhesion molecules in subjects with low HDL-cholesterol. Arterioscler Thromb Vasc Biol 2002; 22: 656 661

${ }^{44}$ Chen NG, Holmes M, Reaven GM. Relationship between insulin resistance, soluble adhesion molecules, and mononuclear cell binding in healthy volunteers. J Clin Endocrinol Metab 1999; 84: 3485- 3489

${ }^{45}$ Chen NG, Azhar S, Abbasi F, Carantoni M, Reaven GM. The relationship between plasma glucose and insulin responses to oral glucose, LDL oxidation, and soluble intercellular adhesion molecule- 1 in healthy volunteers. Atherosclerosis 2000; 152: $203-208$

${ }^{46}$ Hak AE, Pols HA, Stehouwer CD, Meijer J, Kiliaan AJ, Hofman A, Breteler MM, Witteman JC. Markers of inflammation and cellular adhesion molecules in relation to insulin resistance in nondiabetic elderly: the Rotterdam study. J Clin Endocrinol Metab 2001; 86: 4398-4405

${ }^{47}$ Matsumoto K, Miyake S, Yano M, Ueki Y, Tominaga Y. High serum concentrations of soluble E-selectin in patients with impaired glucose tolerance with hyperinsulinemia. Atherosclerosis 2000; 152: 415-420

48 Jager A, Van Hinsbergh VW, Kostense PJ, Emeis JJ, Nijpels G, Dekker JM, Heine RJ, Bouter LM, Stehouwer CD. Increased levels of soluble vascular cell adhesion molecule 1 are associated with risk of cardiovascular mortality in type 2 diabetes: the Hoorn study. Diabetes 2000; 49: $485-491$

${ }^{49}$ Bonora E, Kiechl S, Willeit J, Oberhollenzer F, Egger G, Bonadonna RC, Muggeo M. Metabolic syndrome: epidemiology and more extensive phenotypic description. Cross-sectional data from the Bruneck Study. Int J Obes Relat Metab Disord 2003; 27: 1283-1289

${ }^{50}$ Bluher M, Unger R, Rassoul F, Richter V, Paschke R. Relation between glycaemic control, hyperinsulinaemia and plasma concentrations of soluble adhesion molecules in patients with impaired glucose tolerance or Type II diabetes. Diabetologia 2002; 45: 210-216

${ }^{51}$ Caballero AE, Arora S, Saouaf R, Lim SC, Smakowski P, Park JY, King GL, LoGerfo FW, Horton ES, Veves A. Microvascular and macrovascular reactivity is reduced in subjects at risk for type 2 diabetes. Diabetes 1999; 48: 1856 - 1862

52 Targher G, Bonadonna RC, Alberiche M, Zenere MB, Muggeo M, Bonora E. Relation between soluble adhesion molecules and insulin sensitivity in type 2 diabetic individuals: role of adipose tissue. Diabetes Care 2001; 24: $1961-1966$

53 Matsumoto K, Sera Y, Abe Y, Ueki Y, Miyake S. Serum concentrations of soluble vascular cell adhesion molecule- 1 and E-selectin are elevated in insulin-resistant patients with type 2 diabetes. Diabetes Care 2001; 24: $1697-1698$

${ }^{54}$ Steiner M, Reinhardt KM, Krammer B, Ernst B, Blann AD. Increased levels of soluble adhesion molecules in type 2 (non-insulin dependent) diabetes mellitus are independent of glycaemic control. Thromb Haemost 1994; 72: 979-984

${ }^{55}$ Devaraj S, Jialal I. Low-density lipoprotein postsecretory modification, monocyte function, and circulating adhesion molecules in type 2 diabetic patients with and without macrovascular complications: the effect of alpha-tocopherol supplementation. Circulation 2000; 102: $191-196$

${ }^{56}$ Kado S, Nagata N. Circulating intercellular adhesion molecule-1, vascular cell adhesion molecule-1, and E-selectin in patients with type 2 diabetes mellitus. Diabetes Res Clin Pract 1999; 46: 143 - 148

${ }^{57}$ Guler S, Cakir B, Demirbas B, Yonem A, Odabasi E, Onde U, Aykut O, Gursoy G. Plasma soluble intercellular adhesion molecule 1 levels are increased in type 2 diabetic patients with nephropathy. Horm Res 2002; 58: $67-70$

${ }^{58}$ Kawamura T, Umemura T, Kanai A, Uno T, Matsumae H, Sano T, Sakamoto N, Sakakibara T, Nakamura J, Hotta N. The incidence and characteristics of silent cerebral infarction in elderly diabetic patients: association with serum-soluble adhesion molecules. Diabetologia 1998; 41: $911-917$

59 Takeuchi N, Kawamura T, Kanai A, Nakamura N, Uno T, Hara T, Sano T, Sakamoto N, Hamada Y, Nakamura J, Hotta N. The effect of cigarette smoking on soluble adhesion molecules in middle-aged patients with Type 2 diabetes mellitus. Diabet Med 2002; 19: 57-64 
${ }^{60}$ Leinonen ES, Hiukka A, Hurt-Camejo E, Wiklund O, Sarna SS, Mattson HL, Westerbacka J, Salonen RM, Salonen JT, Taskinen MR. Low-grade inflammation, endothelial activation and carotid intima-media thickness in type 2 diabetes. J Intern Med 2004; 256: 119-127

${ }^{61}$ Becker A, Van Hinsbergh VW, Jager A, Kostense PJ, Dekker JM, Nijpels G, Heine RJ, Bouter LM, Stehouwer CD. Why is soluble intercellular adhesion molecule-1 related to cardiovascular mortality? Eur J Clin Invest $2002 ; 32: 1-8$

${ }^{62}$ Schmidt AM, Crandall J, Hori O, Cao R, Lakatta E. Elevated plasma levels of vascular cell adhesion molecule-1 (VCAM-1) in diabetic patients with microalbuminuria: a marker of vascular dysfunction and progressive vascular disease. Br J Haematol 1996; 92: 747 - 750

${ }^{63}$ Koga M, Otsuki M, Kubo M, Hashimoto J, Kasayama S. Relationship between circulating vascular cell adhesion molecule- 1 and microvascular complications in type 2 diabetes mellitus. Diabet Med 1998; 15 : $661-667$

${ }^{64}$ Lim SC, Caballero AE, Smakowski P, LoGerfo FW, Horton ES, Veves A. Soluble intercellular adhesion molecule, vascular cell adhesion molecule, and impaired microvascular reactivity are early markers of vasculopathy in type 2 diabetic individuals without microalbuminuria. Diabetes Care 1999; 22: 1865-1870

65 Jager A, Van Hinsbergh VW, Kostense PJ, Emeis JJ, Nijpels G, Dekker JM, Heine RJ, Bouter LM, Stehouwer CD. C-reactive protein and soluble vascular cell adhesion molecule-1 are associated with elevated urin- ary albumin excretion but do not explain its link with cardiovascular risk. Arterioscler Thromb Vasc Biol 2002; 22: 593-598

${ }^{66}$ Stehouwer CD, Gall MA, Twisk JW, Knudsen E, Emeis JJ, Parving HH. Increased urinary albumin excretion, endothelial dysfunction, and chronic low-grade inflammation in type 2 diabetes: progressive, interrelated, and independently associated with risk of death. Diabetes 2002; 51 : $1157-1165$

${ }^{67}$ Yoshizawa M, Nagai Y, Ohsawa K, Ohta M, Yamashita H, Hisada A, Miyamoto I, Miura K, Takamura T, Kobayashi K. Elevated serum levels of soluble vascular cell adhesion molecule-1 in NIDDM patients with proliferative diabetic retinopathy. Diabetes Res Clin Pract 1998; 42: $65-70$

${ }^{68}$ Meigs JB, Hu FB, Rifai N, Manson JE. Biomarkers of endothelial dysfunction and risk of type 2 diabetes mellitus. JAMA 2004; 291: 1978 1986

${ }^{69}$ Stehouwer CD. Endothelial dysfunction in diabetic nephropathy: state of the art and potential significance for non-diabetic renal disease. $\mathrm{Ne}-$ phrol Dial Transplant 2004; 19: 778-781

70 Wong TY, Klein R, Sharrett AR, Duncan BB, Couper DJ, Tielsch JM, Klein $\mathrm{BE}$, Hubbard LD. Retinal arteriolar narrowing and risk of coronary heart disease in men and women. The Atherosclerosis Risk in Communities Study. JAMA 2002; 287: 1153- 1159 